\title{
Experiential Approaches: Effective Pedagogy "for" Entrepreneurship in Entrepreneurship Education
}

\author{
Janeth Malywanga, Yongchuan Shi, Xiaoping Yang \\ College of Innovation and Entrepreneurship, Wenzhou University, Wenzhou, China \\ Email: janethmaliwanga@yahoo.com
}

How to cite this paper: Malywanga, J., Shi, Y. C., \& Yang, X. P. (2020). Experiential Approaches: Effective Pedagogy "for" Entrepreneurship in Entrepreneurship Education. Open Journal of Social Sciences, 8, 311-323.

https://doi.org/10.4236/jss.2020.82024

Received: December 28, 2019

Accepted: February 25, 2020

Published: February 28, 2020

Copyright $\odot 2020$ by author(s) and Scientific Research Publishing Inc. This work is licensed under the Creative Commons Attribution International License (CC BY 4.0).

http://creativecommons.org/licenses/by/4.0/

\begin{abstract}
This paper aims to analyze the effective pedagogy to be used in the field of Entrepreneurship Education in teaching "for" entrepreneurship, by analysis of the available literature of effective approach for Entrepreneurship Education. Findings reveal that Experiential approaches are effective in teaching "for" entrepreneurship. Thus, schools that apply these approaches will train student better. This paper contributes to filling the gap in terms of realistic review on the effective pedagogy in teaching "for" entrepreneurship in Entrepreneurship education field.
\end{abstract}

\section{Keywords}

Experiential Approaches, Entrepreneurship, Education “for” Entrepreneurship, Entrepreneurial Skills

\section{(c) (i) Open Access}

\section{Introduction}

Entrepreneurship is a career field, students who are studying Entrepreneurship must be aware that they are taking it as an occupation of their choice. In his theory of vocation development (1908), Parsons stated that decision to engage in any occupation occurs when a person has achieved: an accurate understanding of her or his individual traits (aptitude, interest, personal abilities); a knowledge of labor market; judgment about their individual traits, skills and labor market. Entrepreneurial skills are said to be necessary for performing all the functions important in this career. These skills are not traits. Lichtenstein and Lyons (2001) said that entrepreneurial skills can be developed through practice and coaching.

Entrepreneurship education is the only tool that can prepare professional en- 
trepreneurs by developing certain entrepreneurial abilities like how to start your own business and the process of innovation in the existing business. Nasrullah et al., (2016) said that students receive this type of education, they should become more confident in their ability to create and evaluate entrepreneurial opportunities, and not only to improve the academic performance. Maresch et al., (2016) said they should be able to secure the resources required to seize.

Teaching "for" Entrepreneurship aim is to produce graduates with mindsets, skills and capabilities to identify and shape opportunities, and develop business ventures (QAA, 2012). Learning "for" entrepreneurship has been associated with learning by doing and knowing how to conduct entrepreneurship through Simulations. (Gibb \& Price, 2014) stated that education "for" entrepreneurship focuses on creating enterprising mindset and experiences what it feels to be an entrepreneur. Learning should be based on creativity, informality, curiosity, emotion, real world problems and opportunities and should take place through entrepreneurial ways (Styliani, 2019).

Scholars have been argued for the pedagogical approaches borrowed from business management to teach "for" entrepreneurship, which has a classroom-based focus and "lecture teaching methodology, basically a stand-and-deliver approach" (Neck and Greene, 2011) which misses the vital stimulation of the "knowing how", the reliance on theories, results in a failure to emphasize the distinctiveness of entrepreneurship and hinders the outcome goal of producing competent entrepreneurs (Solomon, 2008). In this literature review, the objective was set to analyze the effective pedagogy "for" Entrepreneurship education and it's an effective application in teaching and practice.

\section{Methodology}

This research paper adopts a descriptive design to discuss on previous studies related to effective pedagogy "for" Entrepreneurship Education for the period of 2009-2019. The paper does not include the publications and reports of the practitioner that also focuses on Entrepreneurship Education only review the academic publication. In order to get the research papers, the study only searches the online databases using the statements Effective pedagogy for Entrepreneurship education and Teaching "for" Entrepreneurship for the period 2009-2019. The search results offered a lot of papers and out of those only the publications in the journal is considered which was around one hundred ninety-three papers. From this list only fifty-one research papers finally selected for review which contain aforementioned topic. Table was created to present a comprehensive summary of the analysis.

\section{Review of Literature}

\section{Education "for" Entrepreneurship}

Entrepreneurship is among the carriers which need work experience training, due to its heart role of creation and Innovation. Gartner (1998) stated that en- 
trepreneurship is about entrepreneurial individuals creating innovative firms that grow and create value. Shane \& Venkataraman, (2000) said that entrepreneurship is not only creating a new venture but also creating value within organization. Stevenson and Jarillo (1990) viewed entrepreneurship as "a process by which individuals, either on their own or inside organizations, pursue opportunities without regard to the resources they currently control". Gibb, (2005) also pointed out that entreprenuership involves actions that result in creation and renew of value.

Teaching "for" Entrepreneurship aim is to produce graduates with mindsets, skills and capabilities to identify and shape opportunities, and develop business ventures (QAA, 2012) (Pittaway \& Cope, 2007: p. 215). Learning “for" entrepreneurship has been associated with learning by doing and knowing how to conduct entrepreneurship through Simulations". (Gibb \& Price, 2014) stated that education "for" entrepreneurship focus on creating enterprising mindset and experience what it feels to be entrepreneur. Learning should be based on creativity, informality, curiosity, emotion, real world problems and opportunities and should take place through entrepreneurial ways (Styliani, 2019).

The components of education "for "entrepreneurship as suggested in literature include: the acquisition of knowledge, the development of an entrepreneurial support system and the building of entrepreneurial skills. Sijde et al., (2008) suggest that entrepreneurship "for" includes realizing opportunities, as a set of competence, as starting a business and as managing a small company. (Fayolle, 2008) mentioned; raising awareness, teaching techniques tools, how to handle situations and supporting project bearers. (Lackeus, 2014) stated that, students pursuing this type of entrepreneurship education have a genuine interest in starting a new venture.

\section{Entrepreneurial skills}

Cooney (2012) said that starting a venture, creating product or doing any entrepreneurial projects needs application of entrepreneurial knowledge and skills to discern and accessing opportunity. Different entrepreneurial skills and traits such as self-images, specific knowledge, motives and social roles lead to venture birth, survival and its growth, also help entrepreneurs successfully to perform a job role (Tehseen \& Ramayah, 2015).

Chell (2013) defined skills as "multidimensional constructs; they comprise the cognitive, knowledge and what is learnt; the affective, emotional expression and what is experienced; the behaviour, action at strategic, tactical and personal levels; and the context, sectoral, occupational, job and task levels". (Riyanti et al., 2016) discussed those skills by grouping them into two categories of soft skills and hard skills. He argued that Hard skill related to technical for managing or running entrepreneurial activities they include human resources management skills; Marketing skills, production skills; Financial skills. Whereas soft skill related to personality or characteristics of entrepreneur is also divided in two groups. One being soft skill of personality and the other being soft skill of cognitive style. Soft skill of personality includes; initiative, perseverance, performance, 
commitment and self-confident. Soft skills of cognitive style include seeking information, efficiency, systematic planning, problem solving, persuasive skills, influencing others.

\section{Application of Entrepreneurial skills in Entrepreneurial process.}

Scholars have identified how entrepreneurial skills applied in entrepreneurship process. Davila et al., (2003) mentioned technical skills help to identify opportunities based on existing competence. Baron (2004) identifies problem solving skills help in conflict resolution and overcoming stress. Rwigema and Venter (2004) said personal motivation skills help in attaining self efficacy, positive attitudes and commitment. GEM (2003) said adaptability to change skill, help in adapting to technological and innovation progresses. Hankinson (2000) stated that persuasion and negotiation skills help in relationships with suppliers, bankers, directors, managers, shareholders, customers. Nieman (2006) said human resource management skills help in dealing with employee relations. Hankinson (2000) mentioned that creativity skills and innovation skills are useful for development of new innovative products and innovative techniques. Similarly, Man et al., (2002) confirmed that ICT skills help to access critical knowledge about markets, opportunities and businesses. According to OECD (2002) financial management skill help in proper resource needs, understand the financial terminology that investors and venture capitalist use and to proposed the amount profit that venture can make be able to re-compensate their investors and cover the staff's salary. Gartner et al., (1999) said Marketing skill help in identify niche markets, paying customers and to analyze competitors, identifying, quantifying and analyzing potential uncertainties and envisioned risks linked with the opportunity Gartner et al. (1999).

These skills can be utilized in the specific phases of entrepreneurship that is seen more as a process than as a one-off decision to take and should be understood and studied as a cognitive and evolving process (Saukkonen, 2017).

\section{Experiencial Approaches to Learning.}

Experiential approaches to learning refer to those theories and methods which emphaze on learning through action. These theories which develop experience and skills belief that learning effectively occurrs when learners are able to connect concepts, reflect and conceptualize themes. They address the ambition to develop competency, which is understood as the combination of knowledge, skills and attitudes (Sánchez, 2011). They also assert that knowledge is constructed in social interaction (Ylänne \& Nevgi 2003) when a personally responsible participant(s) cognitively, affectively, and behaviourally processes knowledge and skills. (Kolb, 1984) allow learning from experience as it gives possibility to learn from natural consequences, mistakes and success.

Experiential approaches, which are effective in teaching "for" entrepreneurship as discussed in literature include; Action based learning, which was introduced by Reg Revans in 1970s. He believes that no learning without action, and no action without learning. Reg Revans emphasis on collaborative learning and 
experience which takes place in a form of team, with a maximum number of six members, who will be learning through action by performing real tasks oriented or work related tasks. Learning process in team reflect on the actions based on tasks given, which are linked with the specific knowledge or skills to be developed under the guidance of a facilitator (Pedler et al., 2005).

Others are Experiential learning, which was developed by Kolb 1970s, and Problem based learning by Mc Master 1960. Kolb, (1984) explained that individuals learn from experience through an experiential learning cycle, comprise of concrete experience, reflective observation, abstract conceptualization, and active experimentation. He defined experiential learning theory as "the process whereby knowledge is created through the transformation of experience and knowledge that results from the combination of grasping and transforming experience", It allows learners to actively construct knowledge in collaborative groups, whereby, the teacher is a facilitator and not the main source of knowledge. Problem-based learning is designed for students to tackle problems, preferably real life and structured events, in small groups supervised by a facilitator (Hansemark, 1998; Hmelo-Silver, 2004; Neufeld \& Barrows, 1974; Savery, 2006; Schmidt, 1993).

\section{Application of Experiencial approaches in teaching "for" entrepreneur- ship}

The effectiveness of these approaches in teaching "for" entrepreneurship, lies on the manner of the method which is applied in teaching and learning process. Example the extent to which the method allow interaction between learners, and exposing students to real entrepreneurial environment, have higher impact on developing entrepreneurial skills, traits and knowledge. For example, team work helps learner to improve communication skills as they listen to each other's opinion (Taylor, 2016). Team work increases student self-efficacy, uncertainty and ambiguity tolerance and self -insight. (Lackeus, 2013) developed entrepreneurial behaviours, exploration of business ideas, increasing entrepreneurial attitudes, motives and intentions (Gibb \& Price 2014).

Projects enhanced student ability to deal with entrepreneurial challenges such as product design. (Musteen et al., 2018) help students to make a pitch to businesses to attract resources or engagement, developing persuasion skills and confidence as students will use them when pitching the idea towards different areas in the target market (Mason and Arshed, 2013). Develop creative thinking among students generating innovative solution on different problems (Wee, 2004), and generating knowledge related to entrepreneurial process (Kruegar, 2007; Welsha et al., 2016).

Other experience practice such as assignments and presentations make student own their learning, Internship allows students to contacts with local industry and entrepreneurs, also inspire students to engage in entrepreneurship (Oyugi, 2014). allow students to improve other meta-skills. These skills may include networking, time management, communication, creativity, selling, negotia- 
tion skills as well as planning skills. Increase student's interest in becoming an entrepreneur, giving the students real hands-on entrepreneurial experience (Sebora, 2008). Help students to create entrepreneurship value and develop confidence in their carrier (Lackeus et al., 2013).

While experience is a great teacher, it cannot replace what can be best taught in a classroom and vice versa (Wrenn \& Bruce 2009). Application of experiential approaches in classroom implies the use of learner centered-methods to teach the content relate to theories of entrepreneurship, with the goal of active exploration and construction rather than the passivity of lecture attendance and textbook reading (Norman, 2014). These methods include brainstorming, use of video, Recitation recitation, Drill drill and practice, demonstration, assignment, discussion, guided discovery, socratic teaching, inquiry, self-assessment, cooperative groups, contracts and presentations. These methods help entrepreneur student to generate a resource of personal knowledge "for" Entrepreneurship (Garrett, 2008). Classroom learning and field learning should be balanced. Although some researchers suggest that best results for entrepreneurship can be obtained outside classroom (Wren \& Bruce 2009), “Good theory without action is busy work and action without theory is not worth learning" Neck et al. (2014b). The planning for fieldwork, team project and experiments activities should be decided whether to start in second and third year after students being oriented with all theories guiding entrepreneurship field.

\section{Review Summary}

Analysis showed that pedagogical approaches borrowed from business management to teach "for" entrepreneurship, which has a classroom-based focus and lecture teaching methodology, basically a stand-and-deliver approach' hinder the outcome goal of producing competent entrepreneurs. Experiential approaches are effective as they allow interaction both in classroom and outside classroom. They help students create a more tangible link between theory and practice, influenced students "attitude toward entrepreneurship as a career path" (Musteen et al., 2018). Help those students with limited prior entrepreneurial knowledge, as they develop meaning schemes which occur through moving from a controlled process of acquiring knowledge toward an automated process of developing expertise in a field (Hagg, 2017). Help in awakening student's desire and mind-set to develop entreprenefurial skills (Moylan et al., 2016). A comprehensive summary has been presented in Table 1 basing on the research objective, findings and application of the findings in teaching "for" Entrepreneurship.

\section{Conclusion}

In this literature review, the objective was set to analyze the effective pedagogy "for" Entrepreneurship education and it's an effective application in teaching and practice. This paper finds that education "for" Entrepreneurship aim is to produce graduates with mindsets, entrepreneurial skills and capabilities to identify, 
Table 1. Comprehensive summary of the findigs from literature review.

\begin{tabular}{|c|c|c|c|c|}
\hline Author (s) & Title Of The Journal & Objective & Findings & Application In Teaching \\
\hline $\begin{array}{l}\text { Sherman, P.S. } \\
\text { Sebora, T. } \\
\text { Digman, L.A. }\end{array}$ & $\begin{array}{l}\text { Experiential Entrepreneurship } \\
\text { in the Classroom: Effects of } \\
\text { Teaching Methods on } \\
\text { Entrepreneurial Career Choice } \\
\text { Intention. Journal of } \\
\text { Entrepreneurship Education, } \\
\text { Volume 11, } 2008\end{array}$ & $\begin{array}{l}\text { To examines the differences } \\
\text { in various pedagogical } \\
\text { approaches to } \\
\text { Entrepreneurship on career } \\
\text { choice intentions. }\end{array}$ & $\begin{array}{l}\text { Experiential Approach to } \\
\text { entrepreneurship is positively } \\
\text { related to interest in new venture } \\
\text { start up, } \\
\text { Alleviate the fear; give students } \\
\text { real hands-on experiences which } \\
\text { lessen student desire to become } \\
\text { entrepreneurs. }\end{array}$ & $\begin{array}{l}\text { Instructors should be } \\
\text { encouraged to use } \\
\text { experiential methods, } \\
\text { especially in developing } \\
\text { entrepreneurial skills but } \\
\text { not totally avoiding } \\
\text { traditional methods in } \\
\text { teaching }\end{array}$ \\
\hline $\begin{array}{l}\text { Mason, C. } \\
\text { Arshed N. }\end{array}$ & $\begin{array}{l}\text { Teaching entrepreneurship to } \\
\text { university students through } \\
\text { experiential learning Industry } \\
\text { \& higher education. Vol } 27 \text {, no } \\
\text { 6, December 2013, pp 449-463 }\end{array}$ & $\begin{array}{l}\text { To examine The effectiveness } \\
\text { of assignment as experiential } \\
\text { approach in entrepreneurship } \\
\text { education }\end{array}$ & $\begin{array}{l}\text { Assignment such as product } \\
\text { making activities, selling is an } \\
\text { effective learning experience for } \\
\text { the students, as they exposing the } \\
\text { students to the real world of the } \\
\text { entrepreneur }\end{array}$ & $\begin{array}{l}\text { Assignment should be } \\
\text { provided considering the } \\
\text { skills to be developed } \\
\text { learning time and number } \\
\text { Of students }\end{array}$ \\
\hline
\end{tabular}

Dobson, J. A., Jacobs, E. \& Dobson, L.
Toward an Experiential Approach to Entrepreneurship Education. Journal of Higher Education Theory and Practice Vol. 17(3) 2017

Lekoko, M.; The effectiveness of Rankhumise, E.; entrepreneurship education: Ras, $\mathrm{P}$ What matters most? African Journal of Business Management Vol. 6(51), pp. 1202
Investigated the effectiveness Experiential and not theory-laden Practice help student of an experiential approach to courses are necessary in Entrepreneurship education developing entrepreneurial using both within-group and behaviour help student to gain between-group research designs.

Explore and investigate entrepreneurship education at Botswana's two universities learning has great impact to determine and evaluate its effectiveness

The study focuses on the question of how specific characteristics of entrepreneurship courses influence the intention to become an entrepreneur. through mistake, however theory and practice for experience and realize that can pursue entrepreneurship as career better outcome
Entrepreneurship education which incorporates experiential in-equipping students with the relevant entrepreneurial skills and entrepreneurship, Methods competencies that will help them of teaching has great impact. to choose entrepreneurship as a career option. Real entrepreneurial practices help student to experiencing what it takes to become a successful entrepreneur.

Perceived behavioural control can To develop entrepreneurial be changed through various course characteristics such as practical experience, business planning
Effectiveness of Education "for" Entrepreneurship is when students are getting a real sense of

to gain experience and learn there should be a balance of Journal of Entrepreneurship and Small Business, Vol. 13, No. 1, 2011. intention: effective entrepreneurship course characteristics. International.
Maritz A. Brown, C. Chich Jen, S. C.
A Blended Learning Approach To explore a blended learning Experiential learning may be approach to entrepreneurship more conducive to teaching To Entrepreneurship Economics 12, Vol. 2, 2010.

\section{integration of this} pedagogical initiative aimed at infusing entrepreneurial skills and behaviour among students in a higher education setting entrepreneurship. In order to increase experiential learning, the teams' performance-which is a more realistic view of the entrepreneurial activity they should be engaged as opposed to the teaching of general principles. 


\section{Continued}

Lackéus, M Links between Emotions and Investigates links between Learning Outcomes in Entrepreneurial Education, Conference paper at 22: nd Nordic Academy of Management conference (NFF), Reykjavik, Iceland, 21-23 of August 2013

Arasti, Z. A Study of Teaching Methods Falavarjani, M.K. in Entrepreneurship Education teaching meth Imanipour, N. for Graduate Students Higher Entrepreneurship course Education Studies Vol. 2, No. 1; March 2012

Yamakawa, Y. The Focus of Entrepreneurship McKone-Sweet, Education: Pedagogy for K. Hunt, J. Teaching the Entrepreneurial Greenberg, D. Method. Journal of Business and Entrepreneurship, 27(2), 19-46.

Žibeniene, G. \& Earning Methods Of

Virbaliene, R Entrepreneurship Education. The collection of scientific papers 2014, ISSN 1691-5895

Moylan, T., Gallagher, N. Heagney, C. strong emotions and entrepreneurial learning outcomes in an action-based entrepreneurship education program
To identify the appropriate To explore whether a pedagogy method can be developed to teach students entrepreneurial methods
The aim of the article is to discuss existing and recommended learning techniques to develop entrepreneurship

Action based learning help to link Emotion help in formation entrepreneurial learning outcome of entrepreneurial identity with emotions, as it engage and increased self - efficacy interaction with outside world, which are essential for uncertainty and ambiguity in learning environment and team-work experience which are for better outcome sources of emotions

Experiential methods are appropriate methods in Educators should choose methods suitable for entrepreneurship as they help in developing communication improving Communication skills, skills. Assignment, team allows interaction among learners, projects, presentations are as they listen to others opinions, It regarded effective in enforces criticism thinking, developing communication because the students criticize skills which is important as others opinions, allow students to it is applied for formation of experience strategies to deal with customer network, ambiguous and complex negotiation and selling. situations

Experiential methods help simplify the learning of Student need to be exposed

entrepreneurial knowledge, skills, logics and a mindset that can be used across diverse settings entrepreneurship, experiential teaching allow including government, established of entrepreneurship as corporations, non-profits, social career ventures, and of course traditional start-ups.

Learning by doing, learning through experience, methods oriented to the discussion of the learning experience, situation analysis, problem-solving, decision making, critical thinking, development of creativity, are effective for entrepreneurship
Student should be assigned with mentors, who will share real entrepreneurial experience with students.
Exploratory Studies on the use of Experiential Learning in Entrepreneurship Education. Journal of teaching and Learning in Higher Education (AISHE-J) Volume 8, Number 1 (Spring 2016) Page 2532
To investigates one particular type of education, namely entrepreneurship education, and Explores whether experiential learning is used in teaching
The solution to successful entrepreneurship education is the use of experiential learning activities to awaken student's Desire and mind-set to develop entrepreneurial skills as well as providing solid foundations and context (imparting knowledge about entrepreneurs and the entrepreneurial process), to facilitate collective networking opportunities and suitable environments while encouraging self-responsibility for learning.
Application of experiential learning in teaching for entrepreneurship should go hand in hand with Preparation of safe learning environment example; Innovation spaces which allow student to meet with different stake holders. 


\section{Continued}

Kim, J. Y., Choi, The role of problem solving To prove the

D. S., Sung, C. S., ability on innovative behavior Relationship between

\& Park, J. Y.. and opportunity recognition in individual's problem-solving university students. Journal of ability and innovative Open Innovation: Technology, behavior and the pedagogy Market, and Complexity, 2008 that can enhance innovative $4(1), 4$.

The results support the role of entrepreneurship education in creating opportunities for innovative behaviour and problem solving abilities through entrepreneurial learning experiences, the more entrepreneurial experiences the greater the chance of new opportunities and development of innovative behavior

Olokundun, M. The effect of non traditional Moses, C.L. teaching methods in

Iyiola, $\mathrm{O}$.

Ibidunni, S. entrepreneurship education on students entrepreneurial

Ogbari, M. Peter, interest and business startups:

F. Borishade, T. A data article, Data in Brief 19 (2018) 16-20,

Olokundun,

M.A. Ibidunni, Shared Vision: A Focus On A.S. Peter, F. Identification Of Business Amaihian, A.B. Opportunities By Nigerian Moses, C.L. University Students. Journalo Entrepreneurship Education Volume 20, Issue 2, 201
To examine the effect of experiential teaching methods and university entrepreneurial interest on students' business startup
The analysis showed that the adoption of experiential practical activities considered as best practices in entrepreneurship teaching can stimulate students' interest and drive for engaging in business start-up activities

To determine the effects of entrepreneurship pedagogy on students' shared vision and identification of business opportunities.

Experiential pedagogy significantly affects students' Experiential Pedagogy And Iyiola, O.O shared-vision for identification of Members interest is business opportunities as important to consider when indication of entrepreneurial forming group intentions. Through unstructured group activities which give learners the opportunity to practice how to identify business opportunities, creative solutions to challenges in situations of risk, and conditions of instability.

Fatoki, O.
An Examination of the Teaching Methods for Entrepreneurship at a South African University, Mediterranean Journal of Social Africa Universities Sciences, Vol 5 No 23 November 2014 to identify the traditional and Traditional methods such as non-traditional pedagogies employed for the teaching of entrepreneurship at South lectures, help students to develop construct and study the theories related to entrepreneurship and firm creation. They are less effective in encouraging entrepreneurial attributes.
Experiential methods such as visit to business, working for a business through industrial training, developing a venture whilst studying and inviting guest speakers, provide students with experiences of new venture and develop entrepreneurial decision making skills

Educators should consider student reaction of the experiential method used in learning process
High level of student satisfaction and Engagement caused by learning style experiential approach had, which in many instances, helped to develop entrepreneurial traits.
Bell, R.

\footnotetext{
an experiential learn approach on the perceived gain experience and thrive. The development of International Journal of entrepreneurial traits. Management Education, 13(1), 37-47.

Developing the next generation To determine the impact of of entrepreneurs: Giving
}

Innovation is the heart role of entrepreneurs. Educators should apply the methods which will help students to skills, this skills has potential role on innovation.
Start-up activities can start when student has been oriented to the theory guided practice.

Group activities should be 


\title{
Continued
}

Rae, D., \&

Wang, C. L.
Entrepreneurial learning: past research and future challenges. In Entrepreneurial learning (pp. 25-58). Routledge
To investigate the challenges The learning styles should in learning Entrepreneurship as revealed in literature. correspond to three key challenges in the entrepreneurship, namely the need for integrating individual opportunity, the need for developing skills and resources required for opportunity exploration and exploitation; and the need for understanding how entrepreneurial opportunities come about.
Ramsgaard, M.

B., \& Christensen, M. E.
Interplay of entrepreneurial learning forms: a case study of experiential learning settings. Innovations in Education and Teaching International, 55(1), 55-64. to explore the action based

learning processes occurring in experiential learning settings and curriculum development
Combining explanation-based help to foster student engagement in teaching for also working with real-life projects in both approaches was seen as vital to the learning process for entrepreneurship.

\author{
Traditional methods are less \\ effective to those challenges. \\ Application of experiential \\ methods in teaching should \\ be considered

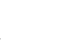

\begin{abstract}
About, for, in or through
\end{abstract}
To develop a new framework Action-based learning methods

Mäkimurtofor EE at the university level.

Koivur
Belt, $\mathrm{P}$. education. European Journal of Engineering Education, 41(5), 512-529. 555

\section{are highlighted to be used in the beginning of studies to support students' personal growth in entrepreneurship}

\author{
Action based learning \\ should be gradually \\ increased only when specific \\ field knowledge has been \\ adequately accumulated.
}

\begin{tabular}{|c|c|c|c|c|}
\hline $\begin{array}{l}\text { Dagdilelis, V. } \\
\text { Giossi, S. }\end{array}$ & $\begin{array}{l}\text { Teaching Entrepreneurship In } \\
\text { Innovative Ways. 11 } \\
\text { International Conference Of } \\
\text { Asecu “Openness, Innovation, } \\
\text { Efficiency And } \\
\text { Democratization As } \\
\text { Preconditions For Economic } \\
\text { Development" (P. 404). } 244\end{array}$ & $\begin{array}{l}\text { To suggest the effective ways } \\
\text { of teaching of creativity, } \\
\text { innovation and } \\
\text { entrepreneurship }\end{array}$ & $\begin{array}{l}\text { practice is very important to } \\
\text { teaching creativity and innovation } \\
\text { in entrepreneurship as it helps } \\
\text { students develop their } \\
\text { entrepreneurial thinking through } \\
\text { play, empathy, experimentation, } \\
\text { creation and reflection. }\end{array}$ & $\begin{array}{l}\text { To enhance practical } \\
\text { teacher can take a role of a } \\
\text { mentor with high expertise, } \\
\text { the role of a change agent } \\
\text { and the role of a leader who } \\
\text { is committed to enhance } \\
\text { students' confidence and } \\
\text { autonomy in order to be } \\
\text { capable of creating } \\
\text { innovative ideas and taking } \\
\text { entrepreneurial initiatives. }\end{array}$ \\
\hline
\end{tabular}

shape opportunities and develop business ventures, the study also finds that traditional approaches such as lecture and reading the text have little impact on the decision about entrepreneurship as a career, and these approaches make students less interested in becoming an entrepreneur, which would seem to defeat the goals of education "for" entrepreneurship. Learning activities that are more experiential in nature have a greater impact on developing entrepreneurial skills and the decision to become an entrepreneur. This study provides evidence that experiential approaches are effective pedagogy "for" Entrepreneurship. Educators should apply them so as to get professional entrepreneurs who can make the world a better place for living. 


\section{Conflicts of Interest}

The authors declare no conflicts of interest regarding the publication of this paper.

\section{References}

Arasti, Z., Falavarjani, M. K., \& Imanipour, N. (2012). A Study of Teaching Methods in Entrepreneurship Education for Graduate Students. Higher Education Studies, 2, 2-10. https://doi.org/10.5539/hes.v2n1p2

Bell, R. (2015). Developing the Next Generation of Entrepreneurs: Giving Students the Opportunity to Gain Experience and Thrive. The International Journal of Management Education, 13, 37-47. https://doi.org/10.1016/j.ijme.2014.12.002

Chell, E. (2013). Review of Skills and the Entrepreneurial Process. International Journal of Entrepreneurial Behaviour \& Research, 19, 6-31. https://doi.org/10.1108/13552551311299233

Dobson, J. A., Jacobs, E., \& Dobson, L. (2017). Toward an Experiential Approach to Entrepreneurship Education. Journal of Higher Education Theory and Practice, 17, 57-69.

Fayolle, A. (2008). Entrepreneurship Education at a Crossroads: Towards a More Mature Teaching Field. Journal of Enterprising Culture, 16, 325-337. https://doi.org/10.1142/S0218495808000211

Gartner, W. B. (1988). “Who Is an Entrepreneur?” Is the Wrong Question. American Journal of Small Business, 12, 11-32. https://doi.org/10.1177/104225878801200401

Gibb, A. (2005). Towards the Entrepreneurial University-Entrepreneurship Education as a Leverage for Change. National Council for Graduate Entrepreneurship.

Gibb, A., \& Price, A. (2014). A Compendium of Pedagogues for Teaching Entrepreneurship (2nd ed.).

Hansemark, O. C. (1998). The Effects of an Entrepreneurship Programme on Need for Achievement and Locus of Control of Reinforcement. International Journal of Entrepreneurial Behaviour \& Research, 4, 28-50. https://doi.org/10.1108/13552559810203957

Hmelo-Silver, C. E. (2004). Problem-Based Learning: What and How Do Students Learn? Educational Psychology Review, 16, 235-266. https://doi.org/10.1023/B:EDPR.0000034022.16470.f3

Kim, J. Y., Choi, D. S., Sung, C. S., \& Park, J. Y. (2018). The Role of Problem Solving Ability on Innovative Behavior and Opportunity Recognition in University Students. Journal of Open Innovation: Technology, Market, and Complexity, 4, 4. https://doi.org/10.1186/s40852-018-0085-4

Kolb, D. A. (1984). Experiential Learning: Experience as the Source of Learning and Development (Vol. 1). Englewood Cliffs, NJ: Prentice-Hall.

Lackéus, M. (2013). Links between Emotions and Learning Outcomes in Entrepreneurial Education. Conference paper at 22nd Nordic Academy of Management Conference (NFF), Reykjavik, Iceland, 21-23 of August 2013.

Mäkimurto-Koivumaa, S., \& Belt, P. (2016). About, for, in or through Entrepreneurship in Engineering Education. European Journal of Engineering Education, 41, 512-529. https://doi.org/10.1080/03043797.2015.1095163

Maritz, A., Brown, C., \& Chich Jen, S. C. (2010). A Blended Learning Approach To Entrepreneurship Education. Actual Problems of Economics, 2, 83-93.

Mason, C., \& Arshed, N. (2013). Teaching Entrepreneurship to University Students 
through Experiential Learning. Industry \& Higher Education, 27, 449-463.

https://doi.org/10.5367/ihe.2013.0180

Moylan, T., Gallagher, N., \& Heagney, C. (2016). Exploratory Studies on the Use of Experiential Learning in Entrepreneurship Education. Journal of Teaching and Learning in Higher Education, 8, 25-32.

Mueller, S. (2011). Increasing Entrepreneurial Intention: Effective Entrepreneurship Course Characteristics. International Journal of Entrepreneurship and Small Business, 13, 55-74. https://doi.org/10.1504/IJESB.2011.040416

Musteen, M., Curran, R., Arroteia, N., Ripollés, M., \& Blesa, A. (2018). A Community of Practice Approach to Teaching International Entrepreneurship. Administrative Sciences, 8, 56. https://doi.org/10.3390/admsci8040056

Nasrullah, S., Khan, M. S., \& Khan, I. (2016). The Entrepreneurship Education and Academic Performance. Journal of Education and Practice, 7, 1-4.

Neck, H. M., Greene, P. G., \& Brush, C. G. (2014). Teaching Entrepreneurship: A Practice-Based Approach. Northampton, MA: Edward Elgar Publishing, Inc. https://doi.org/10.4337/9781782540564

Olokundun, M., Moses, C. L., Iyiola, O., Ibidunni, S., Ogbari, M., Peter, F., \& Borishade, T. (2018). The Effect of Non-Traditional Teaching Methods in Entrepreneurship Education on Students Entrepreneurial Interest and Business Startups: A Data Article. Data in Brief, 19, 16-20. https://doi.org/10.1016/j.dib.2018.04.142

Pittaway, L., \& Cope, J. (2007). Simulating Entrepreneurial Learning: Integrating Experiential and Collaborative Approaches to Learning. Management learning, 38, 211-233. https://doi.org/10.1177/1350507607075776

QAA (2012). Enterprise and Entrepreneurship Education: Guidelines for UK Higher Education Providers. Draft Publication for Consultation, Gloucester: Quality Assurance Agency.

Rae, D., \& Wang, C. L. (2015). Entrepreneurial Learning: Past Research and Future Challenges. In Entrepreneurial Learning (pp. 25-58). London: Routledge. https://doi.org/10.4324/9781315857817

Sánchez, J. C. (2011). University Training for Entrepreneurial Competencies: Its Impact on Intention of Venture Creation. International Entrepreneurship and Management Journal, 7, 239-254. https://doi.org/10.1007/s11365-010-0156-X

Savery, J. R. (2006). Overview of Problem-Based Learning: Definitions and Distinctions. Interdisciplinary Journal of Problem-Based Learning, 1, 9-20. https://doi.org/10.7771/1541-5015.1002

Schmidt, H. G. (1993). Foundations of Problem-Based Learning: Some Explanatory Notes. Medical Education, 27, 422-432. https://doi.org/10.1111/j.1365-2923.1993.tb00296.x

Sebora, T. C. (2008). Experiential Entrepreneurship in the Classroom: Effects of Teaching Methods on Entrepreneurial Career Choice Intention. Journal of Entrepreneurship Education, 11, 29-42. https://www.researchgate.net/publication/257964122

Shane, S., \& Venkataranan, S. (2000). The Promise of Entrepreneurship as a Field of Excellence. Academy of Management Review, 25, 217-226. https://doi.org/10.5465/amr.2000.2791611

Tehseen, S., \& Ramayah, T. (2015). Entrepreneurial Competencies and SMEs Business Success: The Contingent Role of External Integration. Mediterranean Journal of Social Sciences, 6, 50-61. https://doi.org/10.5901/mjss.2015.v6n1p50

Wee, K. N. L. (2004). A Problem-Based Learning Approach in Entrepreneurship Educa- 
tion: Promoting Authentic Entrepreneurial Learning. International Journal of Technology Management, 28, 685-701. https://doi.org/10.1504/IJTM.2004.005777

Wrenn, J., \& Wrenn, B. (2009). Enhancing Learning by Integrating Theory and Practice. International Journal of Teaching and Learning in Higher Education, 21, 258-265.

Yamakawa, Y., McKone-Sweet, K., Hunt, J., \& Greenberg, D. (2016). Expanding the Focus of Entrepreneurship Education: Pedagogy for Teaching the Entrepreneurial Method. Journal of Business and Entrepreneurship, 27, 19-46.

Žibeniene, G., \& Virbaliene, R. (2014). Learning Methods of Entrepreneurship Education. The Collection of Scientific Papers, 2014, 123-133.

https://doi.org/10.17770/ercs2014.1134 